\title{
Properties of ceramic oxides processed by laser
}

\author{
M. Virto ${ }^{(*)}$, J.I. Peña ${ }^{(*)}$, J.C. Díez ${ }^{(*)}$ and G.F. de la Fuente ${ }^{(*)}$
}

\begin{abstract}
Laser floating zone melting method is of relevant importance. The high absorbance of the energy generated by $\mathrm{CO}_{2}$ and $\mathrm{Nd}: \mathrm{YAG}$ laser systems into ceramics specimens allows its transformation in monocrystals structures $\left(\mathrm{ZrO}_{2}\right.$ or $\left.\mathrm{Al}_{2} \mathrm{O}_{3}\right)$, in eutectic crystals $\left(\mathrm{ZrO}_{2}-\mathrm{Ca}\right)$, or in textured polycrystal as $\mathrm{Bi}_{2} \mathrm{Sr}_{2} \mathrm{CaCu}_{2} \mathrm{O}_{8}$. The flexible control of laser parameters allows to obtain products with interesting properties.
\end{abstract}

Keywords: Laser floating zone. $\mathrm{CO}_{2}$ laser. Nd:YAG laser. Ceramics.

\section{Propiedades de óxidos cerámicos procesados con láser}

\begin{abstract}
Resumen La utilización de equipos láser como fuente de calor para el procesado de cerámicas presenta importantes ventajas, como el alcanzar temperaturas muy elevadas, próximas a los $3000 \mathrm{C}$, efectuar tratamientos muy localizados en superficies sin afectar el volumen del material, así como la realización de tratamientos en zonas de dificil acceso, entre muchas otras.

La fusión zonal asistida por láser constituye actualmente una de las técnicas más versátiles en el campo del crecimiento cristalino; la elevada absorción de la energía láser generada con sistemas $\mathrm{CO}_{2}$ y YAG:Nd en el interior de un compacto cerámico permite su eficaz transformación en monocristal, como es el caso del $\mathrm{ZrO}_{2}$ y $\mathrm{Al}_{2} \mathrm{O}_{3}$, eutéctico monocristalino de dos o más fases, caso del $\mathrm{ZrO}_{2}-\mathrm{CaO}$, o policristal texturado como el superconductor $\mathrm{Bi}_{2} \mathrm{Sr}_{2} \mathrm{CaCu}_{2} \mathrm{O}_{8}$. La flexibilidad de control de los parámetros de crecimiento permite obtener productos con propiedades muy atractivas para su utilización en dispositivos de diversa naturaleza y de gran interés comercial.
\end{abstract}

Palabras clave: Fusión zonal. $\mathrm{CO}_{2}$ láser. Nd:YAG láser. Cerámicas.

\section{EXTENDED ABSTRACT}

The application of laser heating to crystal growth offers considerable advantages compared to other crystal growth techniques also based on the solidification from the melt. Very high temperatures can be achieved because of the high absorptivity of the ceramic oxide compacts when $\mathrm{CO}_{2}$ or $\mathrm{Nd}$ :YAG laser radiation is used. Coherent electromagnetic radiation is focussed by standard optical elements producing a molten zone and a temperature distribution with steep thermal gradients. Adequate focussing of the laser beam provides control over the crystal-melt interface during growth and allows direct observation of these processes.

(*) Instituto de Ciencia de Materiales de Aragón (C.S.I.C. Universidad de Zaragoza). Centro Politécnico Superior de Ingenieros. c/ María de Luna, 3. 50015. Zaragoza (España).
However, some peculiarities related to the properties of the starting materials, in their molten, polycrystaline and single crystal forms, namely absorption coefficients, latent heat of fusion, thermal conductivity, melting point or geometrical configuration of the crystal-melt system, must be taken into consideration.

Among the different laser processing techniques, the laser floating zone (LFZ) method is of relevant importance. It is a crucible-free technique where a well defined, small volume of material is molten and moved along a compacted-powder rod. This procedure allows the growth of high purity crystals with diameters larger or smaller than that of the initial rod, depending on the relation of velocities of the seed and the precursor.

Most of the ceramic oxides are opaque in the 10 $\mathrm{mm}$ region, consecuently $\mathrm{CO}_{2}$ lasers are suitable to produce stable growth conditions. However, this radiation is absorbed almost identically by the 
crystal and the melt, making difficult to control temperature gradients at the growth interface. On the other hand, $\mathrm{CO}_{2}$ radiation is absorbed so efficiently by most refractory materials that only small diameter homogeneous crystals can be produced (less than $3 \mathrm{~mm}$ in diameter).

For large diameter crystals it is useful to work with shorter wavelength lasers, where the melts are opaque in contrast to the corresponding crystals. This need is met with Nd:YAG lasers operating at $1.06 \mathrm{~mm}$. Furthermore, due to this difference in absorption between crystal and melt, it is possible to generate temperature fields with improved radial and axial gradients.

In this contribution we describe the application of $\mathrm{CO}_{2}$ and $\mathrm{Nd}$ :YAG lasers for crystal growth. Several materials of various melting temperatures and with different diameters have been grown.
Some of these materials include $\mathrm{ZrO}_{2}, \mathrm{Al}_{2} \mathrm{O}_{3}, \mathrm{ZrO}_{2}$ based eutectics, textured $\mathrm{Bi}_{2} \mathrm{Sr}_{2} \mathrm{CaCu}_{2} \mathrm{O}_{8}$ superconductors among others.

Ceramic eutectics have a great microstructural stability up to temperatures close to their melting point, very good bonding between phases and, compared with single crystals, much higher resistence to thermal shock. The LFZ technique has been confirmed as a very convenient way for growing highly oriented eutectic structures showing a long-range ordered distribution of the constituent phases, opening new perpectives for these "in situ" composites, in addition to their structural applications.

The photographs (Figure 1) show selected regions of transverse ( $\mathrm{a}, \mathrm{b}$ and $\mathrm{c}$ ) and longitudinal (d) sections of typical eutectic fibers grown by the LFZ method using a $\mathrm{CO}_{2}$ laser system described elsewhere (1). Applications of these materials as
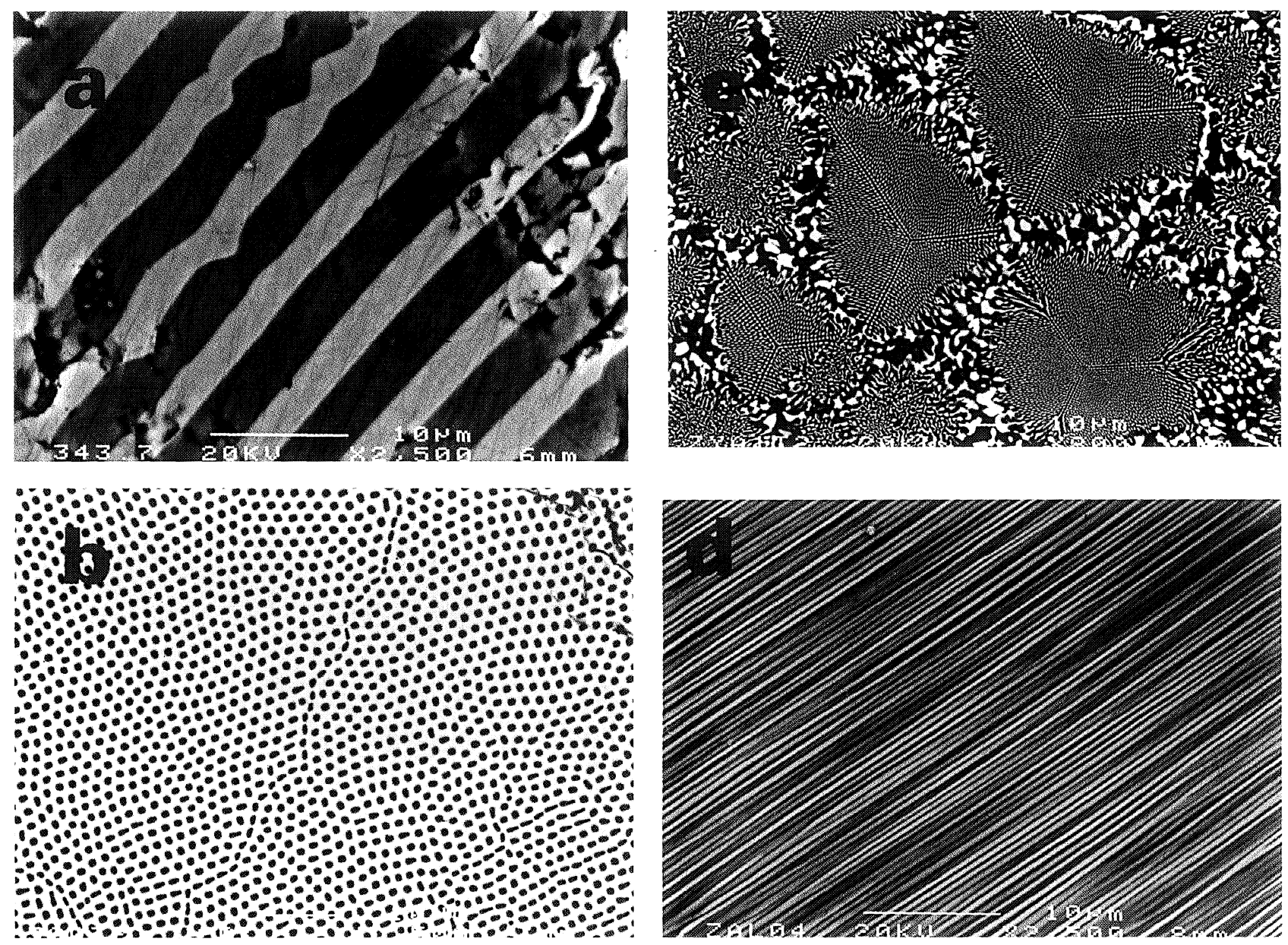

FIG. 1.- Micrografías SEM obtenidas de diferentes fibras eutécticas: (a), (b) y (c) corresponde a secciones transversales de $\mathrm{CaZrO}_{3}$ (fase oscura) - $\mathrm{ZrO}_{2}, \mathrm{MgO}$ (fase oscura) - $\mathrm{ZrO}_{2}$ y Al $\mathrm{O}_{3}$ (fase oscura) - $\mathrm{ZrO}_{2}\left(\mathrm{Y}_{2} \mathrm{O}_{3}\right.$ ) respectivamente. (d) es una sección longitudinal de $\mathrm{Al}_{2} \mathrm{O}_{3}$ (fase oscura) - $\mathrm{ZrO}_{2}$.

Fig. 1.- SEM micrographs obtained from different eutectic fibers: (a), (b) and (c) correspond to transversal sections of $\mathrm{CaZrO}_{3}$ (dark phase) - $\mathrm{ZrO}_{2}, \mathrm{MgO}$ (dark phase) - $\mathrm{ZrO}_{2}$ and $\mathrm{Al}_{2} \mathrm{O}_{3}$ (dark phase) - $\mathrm{ZrO}_{2}\left(\mathrm{Y}_{2} \mathrm{O}_{3}\right.$ ) respectively. (d) is a longitudinal section of $\mathrm{Al}_{2} \mathrm{O}_{3}$ (dark phase) - $\mathrm{ZrO}_{2}$. 
substrates, optical guides (2), coatings and solid electrolytes $(3,4)$ are under consideration.

Polycristalline ceramic superconductors $\left(\mathrm{Bi}_{2} \mathrm{Sr}_{2} \mathrm{CaCu}_{2} \mathrm{O}_{8}\right.$ y $\mathrm{Bi}_{2} \mathrm{Sr}_{2} \mathrm{Ca}_{2} \mathrm{Cu}_{3} \mathrm{O}_{10}$ ) have also been processed by LFZ obtaining textured materials in fiber form with improved transport properties. The best results correspond to fibers with critical current density values at $77 \mathrm{~K}$ up to $6000 \mathrm{~A} / \mathrm{cm}^{2}$ (5). Radiation of $1.06 \mathrm{~mm}$ (Nd:YAG) seems to be more appropiate than $10.6 \mathrm{~mm}$ radiation $\left(\mathrm{CO}_{2}\right)$ for $\mathrm{BSCCO}$ superconductors on the basis of the different degrees of texture observed (1).

\section{REFERENCES}

(1) De la Fuente, G.F., Díez, J. C., Angurel, L.A., Peña, J. I., Sotelo, A and Navarro, R. Adv. Mater. 7, 1995: 853-856.

(2) Orera, V.M., Peña, J.I., Merino, R.I., LÁzaro, J.A., Valles J.A and Rebolledo, M.A. Appl. Phys. Letters. 71, 1997:

(3) Merino, R., Peña, J. I., de la Fuente, G.F. and Orera, V.M. Solid State Ionics. 100, 1997:313-318

(4) Peña, J. I., Merino, R.I., DE la Fuente, G.F. and Orera, V.M. Adv. Mater. 8, 1996: 906-909.

(5) Angurel, L.A., Díez, J.C., Martínez, E., Peña, J.I., DE LA Fuente, G.F. and Navarro, R. (submitted to Physica C). 